\title{
AZ ETNICITÁS DILEMMÁJA A SZÉKELYFÖLD TURIZMUSFEJLESZTÉSÉBEN
}

\author{
(The Dilemma of Ethnicity in the Tourism Development \\ in Szekelyland)
}

HORVÁTH ALPÁR

\begin{abstract}
Kulcsszavak:
turizmusfejlesztés regionalizáció turisztikai desztináció etnicitás etnikai turizmus Székelyföld

A Székelyföld Románia és a Kárpát-medence olyan történeti-kulturális régiója, amelynek a sajátosságát a magyar kisebbség tömbszerü elhelyezkedése adja meg. Ha a kisebbségi létben élök etnicitása eröforrásként mozgósitható, akkor a turizmusfejlesztés a kisebbségi léthelyzet javitását, az asszimilációs folyamatok lassitását is elömozdithatja. A Magyarország és Románia közötti magyar-magyar kapcsolatok egyik jellemzöje az etnikai turizmus, ami a székelyföldi vendéglátók számára szerencsés turizmuspiaci konjunktúrát kínált. A székelyföldi turizmusfejlesztés társadalmi-kulturális és politikai környezetének részét képezi az etnikai regionalizmus és az autonómia mozgalmak is. A romániai magyar kisebbség és a román nemzet közötti kapcsolatokat a turizmus akkor mozdithatja elö, ha az etnicitás korlátozó szerepének leküzdésére sikerül stratégiai megoldásokat találni.
\end{abstract}

\section{Bevezetés}

A turizmus és a regionális fejlődés, területfejlesztés kapcsolatának (Aubert 2007) tanulmányozása rendkívül érdekes lehet akkor, ha olyan területi entitásra vonatkoztatjuk, amely esetében a közigazgatási kompetenciák kisebbségi léthez kapcsolódó kulturális és etnikai dimenziókkal egészülnek ki. A Romániában található Székelyföld sajátossága, hogy a román nemzetállam legnagyobb etnikai-nemzeti kisebbségének, a romániai magyarságnak (1,4 millió fó, 6,6\%) a legnagyobb része, mintegy 700 ezer fő e térségben tömbszerüen helyezkedik el (Kocsis 2002a; Kocsis-BottlikTátrai 2006). A magyar anyanyelvü, magyar kultúrán szocializálódott, sőt 1920-ig a magyar államiság iránt lojális és azt védelmező, építő közösség 90 éve kisebbségi léthelyzetben él. Kisebb-nagyobb sikereket elért a kisebbségi kultúra megőrzése és az asszimiláció (a többségbe való beolvadás) megakadályozása terén, de közösségi jövőképében hosszabb távon megnyugtató megoldást a kulturális és területi autonómia megvalósításában látja (Bakk 2004; Győri Szabó 2004; Kántor-Majtényi 2004; Márton 2004; Varga 2004). Olyan társadalmi-gazdasági modernizációt kellene végrehajtani a térségében, ami nemcsak a hagyományos értékek továbbvitelét jelenti, hanem a kisebbségi emberek szülőföldön való boldogulásának feltételeit is megteremti. A közösséghez tartozó egyéneknek le kell dolgozniuk azokat a hátrányokat, 
amelyek egyrészt a periferikus földrajzi fekvésből (Horváth Gy. 2003), másrészt a kisebbségi léthelyzetből, etnicitásuk korlátozó jellegéből fakadnak.

A Székelyföld mint etnikai régió egy sajátos történeti-kulturális térképződmény és a térségben végbemenő esetleges társadalmi-gazdasági fejlődés akár olyan forgatókönyv szerint is alakulhat(na), ami a székely közösség lassú sorvadásához vezethet. Ennek a folyamatnak a legerősebb tényezői a magyar közösség tagjainak elvándorlása, a korszerkezet és a demográfiai megújuló képesség eróziója (Kiss-Csata 2006), ezzel együtt pedig akár a román többségi nemzet tagjainak térfoglalása (lakás és/vagy telekvásárlás) és lassan regionális közösséggé formálódása, elősegítve a térség etnikai térszerkezetének a megváltozását. A turizmus egy olyan tényezőegyüttes, ami a maga gazdasági és kulturális rendszerként való müködése során képes lehet a kisebbségi magyarság etnicitásának korlátozó szerepét fejlesztési erōforrássá alakítani. Ez egyben azt a kérdést is felveti, hogy a turizmuspiac spontán müködése vezethet ide, vagy esetleg kívülről, a turizmus környezetéből kellene a turizmus-rendszer alakulására hatni, sajátos szakpolitikai (Hall 1994; Church 2004; Hall-Jenkins 2004), esetleg desztináció-menedzsment (Ritchie-Crouch 2003; Lengyel M. 2008) eszközökkel?

\section{Régió, regionalizáció, turisztikai desztináció}

A közéleti vitákban problémák adódhatnak abból, ha a régió fogalmának használata során nem tisztázzák a kontextust, azaz, nem rögzítik le, hogy milyen régióról is beszélnek (Benedek 2000; Cocean 2002; Lengyel I.-Rechnitzer 2004; Faragó 2005). A régiófogalom értelmezése kapcsán itt csupán arra az összefüggésre térnénk ki, ami a régió és a turizmusfejlesztés kapcsán megkerülhetetlennek tünik. A területfejlesztés, regionális politika kereteként Romániában is adottak a NUTS 2-es, azaz tervezési-statisztikai és fejlesztési célokat szolgáló régiók, amelyeket a 2004. évi 315-ös, regionális fejlesztésröl szóló törvény szentesített (Benedek 2006). A megyékből felépülő régiók a felülről vezérelt regionalizáció termékei, nem föltétlenül rendelkeznek saját identitással sem, de régión belüli társadalmi-gazdasági vagy területi kohézióval sem. Románia közepén helyzekedik el a Közép régió, ami hat megyéből épül fel: Fehér, Szeben és Brassó megyék mellett, a Székelyföldet is jórészt magában fogalaló Maros, Hargita és Kovászna megyékből (1. ábra). Az egykori székely székek (valamikori közigazgatási egységek, ma legfeljebb sajátos identitást hordozó kistérségek) területe rajzolja ki nagyvonalakban a Székelyföld elhelyezkedését és határait (Vofkori 1998; Horváth Gy. 2003; Horváth A. 2007). 
1. ÁBRA

Románia tervezési-statisztikai régiói és Székelyföld elhelyezkedése Romániában (The Statistical and Planning Regions of Romania and the Location of Szekelyland)

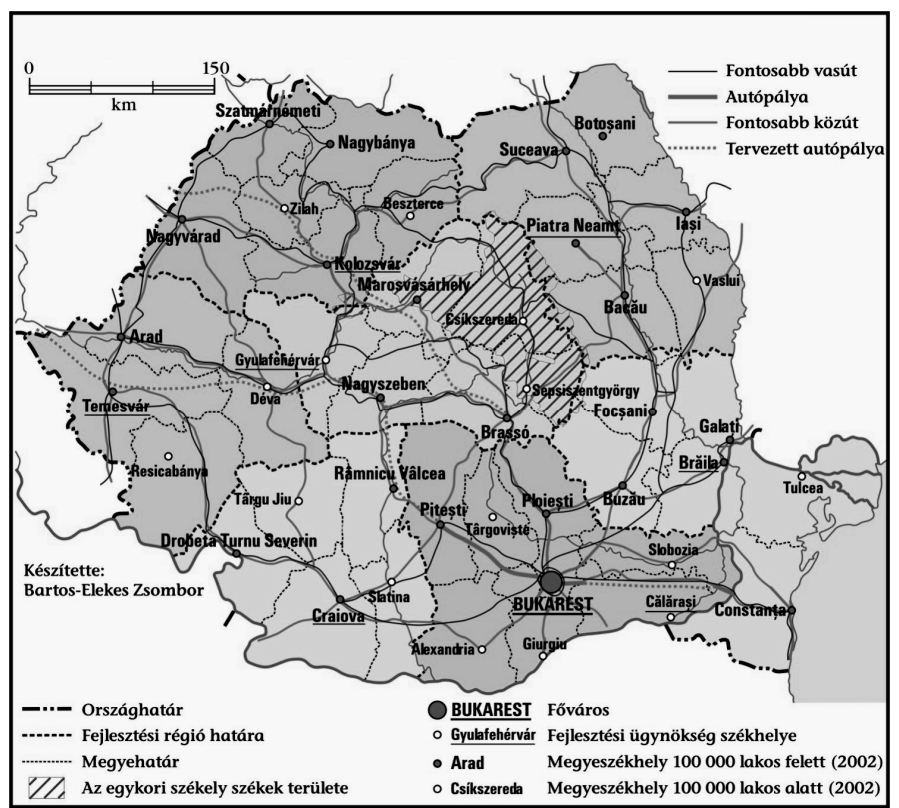

Forrás: Horváth A. (2006) (kartográfus Bartos-Elekes Zs.)

Ha a turizmusfejlödést a turisztikai piac müködésének hatásaként fogjuk fel, akkor tisztáznunk kell ennek keresleti és kínálati oldalát egyaránt (Puczkó-Rátz 2001; Lengyel M. 2004; Michalkó 2007). A turisztikai kereslet közgazdasági fogalmának megfeleltethetjük a turistakibocsátó térség turizmusföldrajzi fogalmát, a turisztikai kínálatnak pedig a turistafogadó térséget, azaz az idegenforgalmi úticélt, turisztikai desztinációt (Ritchie-Crouch 2003; Lengyel M. 2008). Amikor turizmusfejlesztésről gondolkodunk, akkor valójában arra kell választ adnunk, hogy a turizmus-rendszer müködésébe hogyan avatkozik bele az állam, vagy bármilyen olyan szereplö, akinek jogosítványa vagy ereje van a turizmus feltételrendszerének, müködésének, hatásainak befolyásolására (Hall 1994; Church 2004, Aubert 2007).

Turisztikai desztinációk, célterületek akkor is kialakulhatnak egy ország területén, ha a turisztikai kormányzat (turizmusért felelős minisztérium, hatóság, ügynökség stb.) nem jelöl ki turisztikai régiókat, saját irányítási, menedzselési kompetenciákkal. Ha elfogadjuk Agg és Nemes Nagy (2002) álláspontját a „valódi” régió tartalmáról, akkor a turisztikai régió esetében olyan térségről kellene beszélnünk, amely a turizmus révén regionalizálódik. Azaz, a turizmusgazdaság térségi szerveződésében valami sajátosság jelenik meg egyrészt kínálati oldalon, akár mint komplex helytermék, sajátos komplex élménykínálatot ajánlva a látogatók számára. Keresleti oldalon pedig az adott piaci szegmensek jelenlétének kellene valami regionális, azaz nemzeti szint alatti, települési szint feletti specifikus szerveződésének lenni. 
A regionalizálódás a turisztikai régió esetén akár a desztinációvá érést is jelentheti, ami mellé társul(hat) a turisztikai regionalizmus, azaz a turizmus-szektor térségi szereplőinek (önkormányzatoknak, helyi vállalkozóknak, civil szerveződéseknek, általában a kulturális és politikai elitnek) a régióhoz kapcsolódó identitása, „mi”tudata. Ez akár a saját intézmények szerveződéséhez is vezethet, például a regionális szintü turisztikai desztináció-menedzsment rendszer kiépülése révén, ami magával hozhatja a tér lehatárolásának az igényét és (akár felülről is támogatottan) kompetenciákkal való feltöltését. Ez esetben a turisztikai desztináció akár turisztikai régióvá is válhat. Azonban, ha a lehatárolás felülről, a központi kormányzat szintjéről történik, akkor megtörténhet, hogy a központi akarat nem találkozik a helyi, alulról szerveződő-épülő regionalizmussal. Így legfeljebb desztináció jöhet létre a hivatalos, intézményesült turisztikai régiókon belül vagy azok határait átmetszve.

A történelmi fejlődés és kultúra, valamint a regionális identitás lehet az a tényező, amely a turisztikai régiónak megadhatja a sajátos arculatát, de ennek észlelt imázsa azonban, a célpiacok szocializációs folyamatainak és a kommunikációs csatornák müködtetésének függvényében változó lehet térben és időben egyaránt. A desztinációs marketinget, mint a helymarketing (azaz régió- és településmarketing) speciális területét csak vállalkozói tőkéből nehezen lehetséges fenntartani (PiskótiDankó-Schupler 2002; Kozma 2003; Kovács 2004). Ezért az állami-önkormányzati finanszírozás miatt meghatározó a régió normatív jellege (Benedek 2000), az intézményesülés. Ez akár a már létező tervezési-statisztikai vagy programrégiókhoz, területi-közigazgatási egységekhez is kapcsolódhat. Magyarországtól eltérően, Romániában még nem intézményesültek a turisztikai régiók, annak ellenére, hogy az ország történelmi tartományai már keretét képezték desztináció-marketing kiadványoknak (2. ábra). A tervezési-statisztikai, illetve fejlesztési régiók regionális fejlesztési stratégiáiba beépültek a turizmusfejlesztést célzó fejezetek is, de a területiség a turizmuspolitikai gondolkodásban az eddigi kormányzati ciklusok egyikében sem jelent meg markánsan. A sajátos magyar-magyar kapcsolatok turisztikai megnyilvánulása sejtet egy külön desztináció-jelleget egyrészt Erdély, másrészt ezen belül Székelyföld vonatkozásában (Sós-Farkas 2002; Feischmidt 2005; Ilyés 2003; 2005; Sebestyén 2005; Vörös 2005; KPMG 2006; Horváth A. 2009). De ez még nem értelmezhetö turisztikai régióként, legfeljebb annak csíráit, azaz a turisztikai regionalizmus kiindulópontját jelenthetné, ha a térségi turisztikai szolgáltató társadalom, az alulról építkező turizmuspolitika koherens volna. A nemrég megjelent Nemzeti Területrendezési Terv Turizmus szekciója (Legea 190/2009) turisztikai körzetek kialakítását említi, de a jogszabály térképmellékleteiböl nem rajzolódnak ki karakteres, saját arculattal rendelkező régiók, csak ún. turisztikai zónák vagy körzetek, amelyek igazából csak az infrastrukturális fejlesztések prioritását célozzák meg.

Abból a feltételezésből kiindulva, hogy egy turisztikai régiónak mindenekelőtt sajátos identitással s ehhez köthető arculattal kell rendelkeznie, Romániában leginkább a történelmi tartományokra (2. ábra), az egykori fejedelemségek, országrészek területének megfelelő entitásokra, a kisebb néprajzi körzetekre, városrégiókra és csak azután a természeti nagytájakra kellene alapozni a turisztikai régiók kialakítását. 


\section{2. ÁBRA}

Románia történelmi régiói a turisztikai külképviseletek egyikének honlapján (Historical Regions of Romania on the one of the National Tourist Authority's Websites)

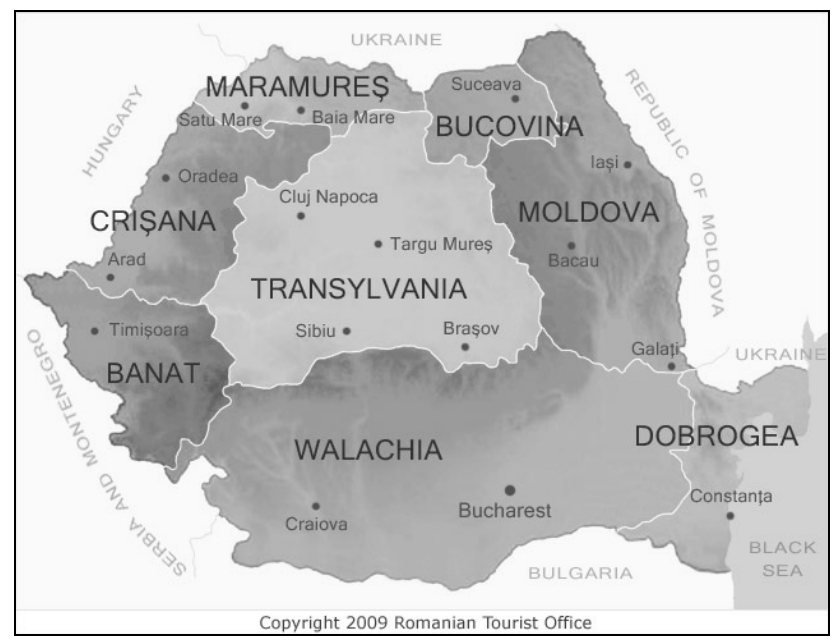

Forrás: http://www.romaniatourism.com/romania-maps/historicalregions-map.html (2009.11.10.).

Bánságnak, Körösvidéknek, ill. Partiumnak és Erdélynek nyilván a multikulturalitása lehetne a differenciáló tényezője, ezen belül pedig Székelyföld megjelenhetne sajátos etnikai-kulturális régió minőségében (Horváth Gy. 2003). De ennek esélye nem vonatkoztatható el egyrészt a székelyföldi regionalizmustól, a belső kohézió megerősítésétől, másrészt attól a többrétű politikai kapcsolatrendszertől, amely a romániai magyar kisebbség autonómia-törekvései és a román többségi társadalom percepcióinak befolyása alatt van.

\section{A Székelyföld mint etnikai régió}

Valódi régió-e a Székelyföld? - tehetnénk fel a kérdést Agg és Nemes Nagy (2002) meghatározása alapján. Van-e mögötte regionalizálódás, irányul-e erre valamilyen regionalizációs törekvés, illetve észlelhetőek-e regionalizmusra, regionális identitásra és intézményépítésre utaló jelek? A három aspektus közül a regionalizációt zárhatnánk ki elvileg a legkönnyebben, hiszen a román nemzetállam kormányzatai részéről az eddigi ,határhúzogatások” a NUTS 2-es régiókra (1. ábra) vonatkoztak, a Székelyföld területi különállóságát, netán autonómiáját támogató hivatalos román(iai) nyilatkozatra csak túlzott optimizmussal lehet számítani. A Székelyföld számára e tekintetben az tekinthető egyedüli pozitívumnak, hogy mindhárom megye, amely a történeti régió egyes részeit magában foglalja egy területi keretbe került. Az utóbbi években a romániai NUTS 2-es régiók működőképes- 
ségét, az EU strukturális alapjainak a lehívásában nyújtott teljesítményeit éles kritikák érték, ami a régiók átszervezése politikai szándékának kinyilvánítását eredményezte (Csutak 2007). A magyarság képviselői értelemszerüen a kisebb régiók kialakítása során a székelyföldinek is nevezett Maros, Hargita és Kovászna megyék alkotta területi entitásért lépnek fel. A regionalizmus oldaláról közelítve a Székelyföldhöz, egyértelmü igazolást találunk a romániai magyar közéleti-politikai diskurzusban, a regionális identitásban, illetve identitásépítési törekvésekben (Kolumbán 2003; Kánya 2003b; Bíró 2007; 2008). Sőt, lassacskán a három megye különböző szereplöinek (önkormányzatok, kulturális intézmények) összefogása, együttmüködési törekvései akár székelyföldi regionális intézményépítés vízióját is előrevetítik (Horváth Gy. 2003). Egyik példát éppen a turisztikai desztináció-marketing csírái (közös turisztikai vásári részvétel) jelentik, amire Hargita megye turizmusfejlesztési stratégiájában külön fejlesztési prioritási tengely is megjelenik (Nagy B. 2009).

Ami a Székelyföldet mint régiót létrehozó regionalizálódást (társadalmigazdasági kohézió kialakulását) illeti, ennek egyedüli biztos jegyét az etnikainemzeti kisebbség tömbszerüségében, sajátos szocializációs és kultúrateremtő közeg mivoltában fedezhetjük fel. Ez az az összetartó erő, ami a székelyföldi magyar etnikai - regionalizmus számára hivatkozási és kiindulási alap lehet. A történelmi fejlődés, az egykori székely székek közjogi különbözősége utalás lehet a hajdani regionalizációs előzményre, azaz a vármegyei rendszerrel 1876-ig párhuzamosan létező széki közigazgatásra (Kánya 2003a). De sem a történeti Székelyföld, sem az azt alkotó egykori székek mint területi entitások (3. ábra) nem váltak ismét normatív régióvá. A regionalizáció, körzetesítés hatalmi kérdés. De amiért az ország törvényei nem bástyázzák körül a kulturális régiót és alegységeit igazgatási kompetenciákkal, az még nem jelenti azt, hogy nem létezik e régió, csak azt, hogy „valódivá válása” idő és hatalmi harc, érdekérvényesítés kérdése. Erről szól a területi autonómiáért való küzdelem (Bakk 2004; Györi Szabó 2004; Kántor-Majtényi 2004; Márton 2004, Varga 2004).

A Székelyföld értelmezése kapcsán kézenfekvő megközelítés a szimbolikusinformális régiófogalom (Benedek 2000) alkalmazása, hiszen a Székelyföld egy olyan területi entitás a Kárpát-medencében ${ }^{1}$ és Romániában, amelynek az elhelyezkedése és mai kiterjedése többé-kevésbé a magyar kultúrához tartozók és/vagy azt ismerők számára evidencia lehet. Határai azonban a történeti, demográfiai és politikai folyamatok hatására már nem egyértelmüek még a régiókban élők számára sem (Vofkori 1998; Kolumbán 2001; 2003; Horváth Gy. 2003). A Székelyföld megnevezés használata utal a 'székelyek földje' jelentéstartalomra, ami már eleve felveti a kérdést: kik is a székelyek? A székelység nem más, mint a magyar kultúrnemzetből kiszakított, romániai magyar nemzeti kisebbség (nemzetrész) egy része, néprajzi csoportja, amelynek önmeghatározásában, közéleti megnyilvánulásaiban az etnicitás és a regionális kultúra, a hagyomány meghatározó szerepet játszik. 


\section{3. ÁBRA}

A székely székek térképe (az egykori Aranyosszék nélkül)

(Map of the Székely ,Széks”/Chairs - without the Aranyos Szék)

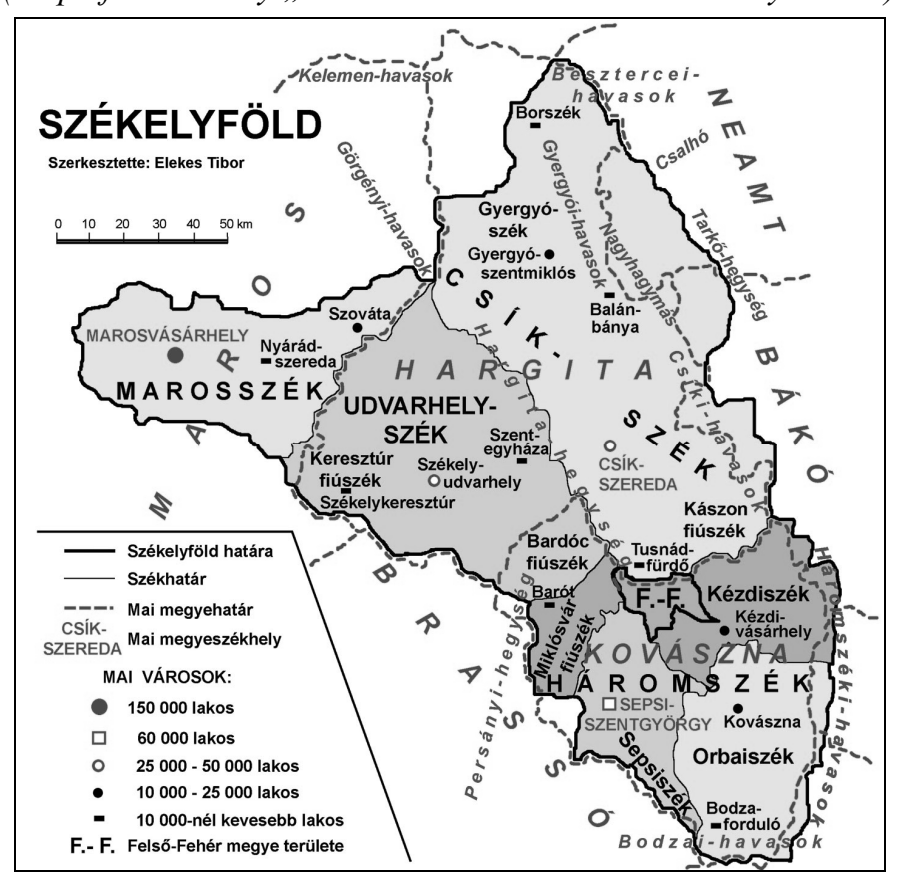

Forrás: Elekes (2009).

Amint Vofkori (1998), Kánya (2003a) vagy Egyed (2006) összegzö leírásaiból kitünik, a székelyek eredettörténete nem tartozik a történettudomány megnyugtatóan tisztázott kérdései közé. A számos elmélet eltérése a székelyek egészen korai, 12-13. század előtti kérdéseivel kapcsolatos. A székelyek saját magukról folytatott narratíváiban, a térségi identifikációs folyamatokban valószínüleg sokkal jelentősebb szerepe van a származás-mítoszoknak, mint a történelemtudományi interpretációknak (Hermann 2007). Annak ellenére, hogy a történelmi Székelyföld egyes területeit valószínüsíthetően több hullámban és több előző telephelyről telepítették ide az Árpád-házi királyok (Kánya 2003a; Egyed 2006), a mai (iskolázottsági szinttől és társadalmi rétegződéstől függően valószínüleg differenciált) közgondolkodásban inkább az az elképzelés él a múltról, amit informális csatornákon keresztül szívhatott magába az egyszerü székely ember és amit a székely himnusz ż ünnepi alkalmakkor való éneklése csak erősít benne: a Csaba-mítosz (Hermann 2007). Ezt a mítoszt élteti a (magyar-magyar) turizmus is, de ugyanakkor táplálkozik is belöle. A székelyek származástudatában az egységes ,nemes székely nemzet” ideája, mint a középkori rendi nemzetfogalomnak (Hermann 2003) a kollektív tudatban megörzött identifikációs formája maradt meg. Sőt, ha kritikusan szemléljük a székely nemzet fogalom anakronisztikus használatát, akkor egyfajta székely nacionalizmusnak is tanúi lehetünk, bár ez inkább az etnikai regionalizmus fogalmával közelíthető meg. Egy 
olyan sajátos területi-közösségi identitásról van szó, amely a magyar nemzet szerves részeként, de azon belül jól elkülöníthetően definiálja önmagát. A magyar nemzeti identitás és a székely regionális identitás összefonódása jelöli ma ki a Székelyföldnek mint identitásrégiónak a határait (Vofkori 1998; Kolumbán 2001; Kánya 2003b;Egyed 2006;).

A középkor folyamán kialakult széki közigazgatási rendszer 1876-ig maradt fenn ${ }^{3}$, addig töltöttek be a székek közigazgatási, bíráskodási funkciót, de a székelyek Árpád-kori privilégiumait az Erdélyi Fejedelemség fennállása alatt már alaposan visszametszette a központi hatalom (Kánya 2003a; Egyed 2006). Székelyföld szerepe a történelem folyamán átértékelödött, a katonai és határőrvédelmi szereppel együtt járó kiváltságok, adómentességek megszüntek, a székely önkormányzatiság, önszerveződés folyamatosan visszaszorult, s bár e területi közösség a változó központi hatalmaknak alárendelt maradt, az önkormányzás, a székelyföldi területi autonómia eszméje meghatározó maradt (vagy feléledt) a mai térségi közgondolkodásban és közbeszédben is. A székely identitás (Kánya 2003b) sajátos megnyilvánulása a székelyföldi regionalizmus, amely több formában, csoport-specifikusan nyilvánul meg, olyan interakciók révén, amelyek a szellemi-kulturális vagy a politikai és közéleti szférában jelennek meg (Kolumbán 2003; Kántor-Majtényi 2004; Bíró 2008). Legnyilvánvalóbb, de nem kizárólagos példája a székelyföldi autonómia-mozgalom (Bakk 2004; Györi Szabó 2004; Kántor-Majtényi 2004; Márton 2004; Varga 2004). A székely identitás a regionális kultúra megnyilvánulása és annak generálója is.

A turizmus révén már müködik egy fajta kívülről jövő, de a belső kohéziót erősítő, a belső szerveződést előmozdító tényező. A turizmusnak ezt a fajta térszervező erejét, amit a keresleti igényekre reflektáló kínálati oldal (vállalkozók, önkormányzatok, civilek) termel ki, feltételesen székelyföldi turisztikai regionalizmusnak is nevezhetjük. Ez hivatott megteremteni a Székelyföld turisztikai desztináció-menedzsmentjét, a fokozatosan és lehetőség szerint alulról kiépülő TDM-szervezet rendszer keretében (Horváth A.-Peteley 2008). A székely kultúra (ami nem más, mint székelyföldi regionális magyar kultúra) szimbolikus elemek segítségével, akár a helymarketing eszköztár (Piskóti-Dankó-Schupler 2002; Kozma 2003; Kovács 2004) tudatos alkalmazásával megjeleníthető a külvilág számára. Ez azt is eredményezheti, hogy nem csak a magyar történelmet többé-kevésbé ismerő, netán azt érzelmi síkon is megélő magyar etnicitású emberek számára lesz felismerhető a székelység mint történeti-kulturális közösség és a Székelyföld mint sajátos régió, hanem a más kultúrákhoz tartozók számára is.

\section{Etnicitás, etnikai turizmus székelyföldi problémái}

Az etnikai régió, az etnikai regionalizmus vagy éppen az etnikai turizmus olyan komplex fogalmak, amelyeket az etnicitás fogalma (Barth 1996; Keményfi 2002; Kocsis 2002b) nélkül nem tudnánk értelmezni. Kocsis Károly definíciója szerint „az etnicitás szó napjainkban egyrészt azt a módot jelenti, ahogyan az egyének 
személyes identitásukat kifejezik, másrészt pedig a társadalmi rétegződés azon típusát tükrözi, mely tényleges vagy vélt közös leszármazáson, kulturális jellemzőkön alapuló csoportképződésböl ered.(...) Különösen nagy lehet az etnikumok belsö kohéziós ereje az etnikai identitás veszélyeztetettségének idején, ha lakóhelyüket egy másik etnikum, egy idegen állam meghódítja, vagy ha idegen környezetbe vándorolnak, vagy ha az elözőekkel összefüggésben etnikai diszkriminációnak vannak kitéve" (Kocsis 2002b, 319-320).

Az etnicitás, valamely etnikumhoz tartozás tudata szorosan kapcsolódik a nemzet és a nemzettudat fogalmához. A nemzetfogalom értelmezése során utalnunk kell arra a kettős megközelítésre, amelyet ugyan számos kritika ért a nacionalizmuselméletek kutatói és kisebbségkutatók, szociológusok, antropológusok, politológusok részéről (Kántor 2007), de a kisebbségi léthelyzetről való gondolkodásban, megfelelő árnyalással jó elméleti fogódzót kínál: a kulturális nemzet és politikai nemzet viszonyára. A nemzet fogalma, tehát, nem egyértelmü, mást jelenthet Nyugat-Európában és Amerikában, mást Kelet- és Közép-Európában (A. Gergely 2005; Egedy 2007; Kántor 2007). Előbbire a politikai nemzet fogalmának dominanciája jellemző, utóbbira a kulturális nemzet fogalma (Györi Szabó 2006).

Kelet-közép-európai térségünkben a nemzetállamok létrejötte egyrészt az első világháború utáni hatalmi szerkezetváltások, másrészt a 19. század közepe óta feltörő nacionalizmusok és nemzetépítési projektek eredménye (Hajdú 2000; Hardi-HajdúMezei 2009). Például a korábban kisebbségi sorban (de számbeli többségben) élő erdélyi, magyarországi románok 1918. december 1-jén kimondták egyesülésüket a királyi Romániával, majd az 1919. évi hatalomátvételt követően, a világháborút lezáró 1920. június 4-i Trianoni békeszerződés szentesítette az új államhatárokat. Ez azt eredményezte, hogy Magyarország mintegy $102813 \mathrm{~km}^{2}$-nyi területét csatolták Romániához, közel 5,3 millió (ebből mintegy 2,8 millió román, 1,6 millió magyar és 557 ezer német nemzetiségü) lakossal (Glatz 1996, 571). Így, tehát 1,6 millió magyar nemzetiségü lakos, a kárpát-medencei magyarság 16,7\%-a került Romániához, azaz kiszakadt a politikai értelemben vett magyar nemzetböl, állampolgári közösségből és nemzeti kisebbségi státusban része lett a román(iai) állampolgári közösségnek.

Ez a folyamat nem volt mentes az egyének, közösségek etnicitásában bekövetkező törésektől, az elszakadás, veszteség érzésétől. Mivel az etnicitás tudata kiélezett helyzetben megerősödik, a nemzeti kisebbségi létbe kerülő egyének életminőségének meghatározója lesz a nemzethez való tartozás megélésének lehetősége (Szarka 1999; 2005b). Amit ma a nemzetpolitikai diskurzusban találóan úgy jellemeznek, hogy a határon túli magyar közösségeknek Trianon után egy szétfejlödése következett be, az arra utal, hogy különböző nemzetállamokban nemzeti kisebbségi státusba került magyar közösségeknek más és más hatalmi szerkezetekben kellett érvényesíteniük érdekeiket. Más és más nyelveken, más nemzeti kultúrákkal kerültek új fajta kapcsolatba, miközben érzelmi és tudati szinten a magyar kultúrával, történelemmel való közösségüket is igyekeztek fenntartani. A határokon túlra került közösségeknek nem szünt meg a kulturális identitáson, nyelvi közösségen, közös történelmi örökségen alapuló kultúrnemzeti hovatartozása. De elkezdődött - többek között - a 
romániai magyarság sajátos kisebbségi társadalomszerveződése, a közösségi és egyéni lét új kontextusban való újragondolása (Szarka 2005b).

Az új politikai-nemzeti (állampolgári közösségi) és kultúrnemzeti hovatartozás kettőssége azonban önmagában még nem feltétlenül kellene a nemzeti kisebbséghez tartozók életérzésének, életminősége szubjektív feltételeinek romlását jelentenie (Szarka 2005a). De az új nemzetállam(ok) homogenizációs törekvései, a mássághoz való jog el nem ismerése a kisebbségi közösségek számára nem az integrációt, hanem az asszimilációt, a lassú vagy gyorsított beolvasztást jelenthetik. Ezt a folyamatot pedig olyan demográfiai folyamatok erősítik, mint az elvándorlás, korszerkezet változása (demográfiai öregedés), negatív természetes szaporulat (KissCsata 2006). Mindezek egyrészt a politikai, a szocio-kulturális vagy a gazdasági feltételekkel függenek össze (Veres 2005; Kocsis-Bottlik-Tátrai 2006).

Azoknak a nemzeti kisebbségeknek, amelyek esetében létezik egy „anyaország”, meghatározó jelentőségű az anyaország külügyi kapcsolatrendszere (Szarka 2007), többek közt a lakóhely szerinti országgal, esetünkben az alapszerződéssel is alátámasztott Magyarország-Románia kapcsolatrendszer. A kisebbségi sorban élő egyének számára nem annyira a diplomácia kulisszái mögötti történések érdekesek, mint inkább az, hogy az anyaország milyen eredményességgel tud a lakóhely szerinti ország kormányzataira, politikai erőire hatni, másrészt az, hogy milyen nemzetpolitikai szempontokat, elveket és eszközöket érvényesít a határon túli nemzetrészekkel való kapcsolattartásban. Ehhez tartoznak a különböző támogatási rendszerek, a határon túli oktatási, kulturális, esetleg gazdasági intézmények fenntartására irányuló erőfeszítések, de ugyanígy, a határon túli közösségekről való diskurzus jellege, ami az anyaországbeli és külhoni magyarok, nemzetrészek közötti érzelmi kapcsolatokat is befolyásolja, ami aztán lecsapódhat a turizmuson keresztüli interakciók jellegében, tartalmában.

A Székelyföldnek mint szimbolikus-informális, azaz történeti-kulturális és etnikai régiónak az identitását nagymértékben erősíti a turizmus fejlődése, egyrészt keresleti oldalról, döntően a magyarországi turisták és utazásszervezők, útikönyvírók részéről, másrészt kínálati oldalról, azaz a keresleti trendhez való proaktív alkalmazkodás, az etnikai turizmus, mint konjunktúra kihasználása által (Feischmidt 2005; Ilyés 2005; Sebestyén 2005; Vörös 2005; Horváth A. 2009). Székelyföld sajátos identitása a történelmi múltban, a múltból átörökített etnikai mítoszokban gyökerezik, ugyanakkor a politikai és közéleti diskurzusban (beleértve a desztináció-marketing vonatkozású érveléseket is) folyamatosan újjáépül. Turisztikai bemutatási technikák (Puczkó-Rátz 2000; Husz 2007) révén a térség történelme, mítoszai, legendái, néprajzi tudása a turizmusban hasznosíthatóak, azaz gazdasági erőforrásokként (Dower 1999; Czene 2002; Ferencz 2003) is felfoghatóak. A Székelyföld turisztikai célterület jellegét alátámasztják az utazás és utazásszervezés nélkülözhetetlen kellékeiként az útikönyvek, turisztikai kalauzok is (Vofkori 1998; Sós-Farkas 2002) és az egyes, föleg a magyarországi turistacsoportokat vezető, kísérő idegenvezetők interpretációi is. Amint a résztvevő megfigyelés és több interjúalannyal készített mélyinterjúk ${ }^{4}$ is igazolják, a helyi idegenvezetök egyfajta kultúraközvetítő szerepet is betöltenek, de nem csupán a történelmi-néprajzi, helytörténeti, egyház- és művészettörténeti ismeretek 
átadása révén, hanem azzal a verbálisan is megjelenített identitással, amely által a helyi idegenvezetők szolgáltatása autentikusabb, mint a küldőpiacról érkező „,profi” utaskísérőé/idegenvezetőé. A fő hozzáadott érték vagy megkülönböztető elem, a „mi”- és „miénk”-tudat megjelenítése.

A székelyföldi vendéglátók, kisvállalkozók eddig egy olyan turistaáramlási konjunktúrát használtak ki, amelyre rásüthetjük az etnikai turizmus (Harron-Weiler 1992) bélyegét. Ennek egyaránt vannak pozitív és negatív vetületei. A magyarmagyar kapcsolatok vendég-vendéglátó szereposztásában a kilencvenes évektől inkább a magyarországi vendég játszotta a turista szerepét, a határon túli, az erdélyi, székelyföldi magyar pedig a vendéglátó szerepét. Magyarország és Románia eltérő gazdasági fejlettsége a két ország viszonyában eddig Magyarországot inkább küldő-, Romániát inkább fogadóterületté tette. Amint személyes tapasztalataim és interjúalanyaim elmondásai is alátámasztották, a magyar turisták egy részének magatartásában néha olyan (sajnálkozó, esetenként lekezelö) viszonyulás volt megfigyelhető, kiérezhető, amelynek eredménye lehet a vendéglátók részéről a kezdeti lelkesedés, eufória halványulása és az apátia irányába való alakulása (Puczkó-Rátz 2001, 152). Ez a fejlemény negatívumként könyvelhető el, akárcsak az az aspektus is, hogy Magyarországról Erdélybe inkább csak azok jöttek el turistaként, akik számára „Erdélybe utazni más” (Sebestyén 2005). Az pozitívum, hogy az utóbbi esetekben inkább az öszinte rajongás tapasztalható Erdély és Székelyföld autentikus értékei iránt. Számukra Erdély nem egy a sok turisztikai desztináció közül, ahová a jó árérték miatt is érdemes elutazni. E szegmens számára szinte erkölcsi parancsként jelentkezik a késztetés, az utazási motiváció. Azért különleges Erdélybe, s ezen belül lehetőleg Székelyföldre utazni, mert a magyar kulturális örökség emlékeit, de még inkább a magyar közösségeket, embereket megismerni a maguk mindennapjaiban egy sajátos élményt, a kognitív és esztétikai mellett, az önmegvalósítással kapcsolatos élményt hordozhat (Puczkó-Rátz 2000; Kovács 2004). Mindemellett egyre többen érkeztek olyanok is, akik számára kevés és homályos információ állt rendelkezésre Erdély realitásairól (többek között arról, hogy csak Székelyföldön jellemző a tömbmagyar jelenlét, illetve, hogy egyáltalán létezik a magyar anyanyelvü közösség). Az ismerősök és utazásszervezők késztetésére ők is útra keltek, a nem egyszer „fapadosnak" ítélt Erdélybe. Egy piackutatási tanulmány (KPMG 2006) megállapításai szerint a magyar piacon meghatározó a „fapados Erdély”-imázs, amit az is igazol többek közt, hogy a Székelyföldre Magyarországról érkezők általában jóval árérzékenyebbek, mint a hazai turisták, illetve, mint saját maguk, belföldi utazásaik során.

Minden pozitívuma mellett ennek a magyar-magyar „etnikai” konjunktúrának az a kedvezőtlen hatása is megvolt, hogy főleg a kisebb turisztikai vállalkozások megelégedtek a magyar piaci jelenléttel, anélkül, hogy nyitottak volna más piacok felé is. Nemcsak a marketingkommunikációs eszközök és csatornák használatát illetően, hanem a nyelvtanulás tekintetében sem voltak jelentős erőfeszítések. A magyar piac stagnálásának, netán szűkülésének az érzékelése alapján (bár a határátlépési statisztika alapján még mindig első helyen állnak a magyarországiak és jóval nagyobb számban, mint egy-két évvel korábban, ld. Horváth A. 2009), több székelyföldi 
vendégfogadó vállalkozás vezetője érzi a román és más külföldi piacok felé való nyitás szükségességét. A kínálat további növekedése és szerkezetváltása hangsúlyozottan veti fel a gazdaságosság és a jobb kapacitáskihasználás kihívásait. Mindezek nemcsak a más földrajzi piacok felé való orientációt, hanem a termékfejlesztési eröfeszitések fokozását is feltételezik. Forgalomnövekedésre akkor lehet számítani, ha egyrészt (akár az Európán kívüli úticélokkal versenyezve) Magyarországról sikerül idecsábítani azokat a szegmenseket, akik számára Erdély még nem, vagy másodszorra már nem tünik vonzónak. Másrészt a belföldi és más országokbeli vendégek és utazásszervezök érdeklődésének a felkeltésére is szükség van. Ez viszont csakis az etnikai turizmus meghaladása vagy átértékelése és stratégiai alapokra való helyezése mellett lehetséges.

\section{Összefoglalás}

Korlátozó tényező-e a fejlődésben, sajátosan a turizmusfejlődésben a kisebbségi léthelyzetben élők etnicitása? Ha egy történeti-kulturális régiónak a kohéziós tényezőjét az etnicitásban, a regionális közösségnek az ország társadalmától való nemzeti alapú tudati-érzelmi elkülönülésében ismerjük fel, akkor értelmezni kell az etnicitásnak mint társadalmi-kulturális tényezőnek a fejlődési kilátásokra való hatásait. A nemzeti kisebbségi léthelyzet az egyének életminőségét akkor befolyásolja kedvezőtlenül, ha etnicitásuk miatt az egyének diszkriminációnak vannak kitéve, nem tudják fenntartani kulturális és szociális intézményeiket és az azok által biztosított szocializációs formákat. A tömbmagyar-jelleg a székelyföldi közösségek számára másfajta szocializációt, másfajta egyéni és csoportos életstratégiákat tesz lehetővé, mint a multietnikus közegben tényleges kisebbségi léthelyzetben élő „szórványmagyarok" számára. A tömbben élő magyar nemzetiségű székelyföldiek nem kényszerülnek napi kapcsolatban lenni a többségi nemzetet alkotó, de regionálisan kisebbségben levő románokkal, ami a nyelvhasználat terén egyfelöl az anyanyelv akadálytalan elsajátítását, fejlödését jelenti, ugyanakkor az állam, illetve a régión kívüli többségi nemzet nyelvének elégtelen ismerete sok esetben korlátozó tényezö, föleg a régión kívüli munkaerő-piaci boldogulásban. Mivel a napi kommunikáció során viszonylag kevés interakcióra kerül sor a nem-magyar nemzetiségủekkel, és mivel a kábeltelevíziós szolgáltatások révén túlnyomórészt a magyarországi média szolgáltatásait fogyasztják, ezért leginkább a közoktatási rendszerben való részvétel, esetleg a munkahelyi szocializáció során sajátítható el és gyakorolható az állam nyelve.

Ha a Székelyföldet turisztikai desztinációként szemléljük, akkor az etnicitáshoz kapcsolódó nyelvhasználat, anyanyelvi kultúra, történelmi tudat egyrészt fejlődési erőforrásként értelmezhető az anyaországgal, mint turistakibocsátó térséggel való kapcsolatban, a formális és informális magyar-magyar kapcsolatrendszereken keresztül. Határforgalmi statisztikák és terepi megfigyelések (Horváth A. 2009) igazolják az anyaország, mint turisztikai piac, a magyarországiak, mint piaci cél- 
szegmens jelentőségét Székelyföld számára. Ez tehát egy szerencsés konjunktúra. A kínálatnak a keresletnél gyorsabb fejlődése azonban előbb-utóbb arra irányítja a figyelmet, hogy nem szerencsés, ha egy idegenforgalmi úticél túlzottan egy piactól, egy vagy egysíkú terméktől függ. Amikor valamilyen kedvezőtlen esemény hatására megcsappan, akár időlegesen is, az adott célpiacról való beutazás, akkor a piaci orientációban fordulópont következhet be, vagy legalábbis egyre több vállalkozás ismeri fel az adott desztinációban, hogy nyitni kell más piacok felé is és/vagy diverzifikálni kell a termékkínálatot. A Székelyföldi turizmus teljesítménymutatóinak alakulása (Horváth A. 2009; Nagy 2009), valamint a térség turizmusban érintettjeivel készített mélyinterjúk alapján felismerhetővé vált egyrészt a székelyföldi turizmust - legalábbis részben - jellemző „etnikai hatás”, vagyis az, hogy a küldőterület lakóinak és a fogadóterület lakóinak, vendégeknek és a vendégfogadóknak az etnicitása, egyazon kulturális nemzethez tartozása piaci potenciált hordoz magában, bár nem föltétlenül elégséges a versenyképességhez. Ha elég erős az etnikai turizmussal kapcsolatos turistaáramlás, akkor az a fogadó ország számára gazdasági előnyöket hordoz (külkereskedelmi mérleg javítása a láthatatlan export által, munkahelyteremtés, adóalap szélesedése stb.). E konjunktúrának a fogadóterületi turizmusszervezők és a küldőpiaci szereplök együttmüködése révén történő, hosszabb távon való fenntartása esetén további kedvező - ezúttal kulturális - hatások várhatóak. A kisebbségi kultúra jelenléte felértékelődik a többségi nemzetnek legalább a turizmusban érintett részénél, a kormányzat számára pedig a külügyi kapcsolatrendszer, a kulturális csere és az európai területi együttmüködés terén nyílhatnak új távlatok. A székelyföldi magyarság megfelelő nyitottságú, gazdasági és kulturális alapozású turizmus-stratégia kidolgozása és végrehajtása révén, az etnicitásnak a többségi nemzettel való viszonyában viszonylag hátrányos voltát éppúgy előnyös adottsággá alakíthatja, mint a kulturális nemzet anyaországi részével való kapcsolatában. A székelyföldi turizmus szereplői ilyen értelemben elősegíthetik egyfelől a magyar kulturális nemzet integrációját, másfelől a magyar kisebbség integrációját (és nem asszimilációját) a román politikai nemzetbe.

\section{Jegyzetek}

\footnotetext{
${ }^{1}$ A Kárpát-medencében mint területi entitás fogalmi keretében való gondolkodás nem kizárólag a Kárpátok hegyláncán belüli nagy medenceség domborzati egységként való megközelítését jelenti, hanem sajátos magyar viszonyulást ahhoz a közép-európai térhez, amelyet a magyar kultúra, a magyar kulturális örökség tárgyi és szellemi emlékeinek jelenléte, az egykori Magyar Királyság területe jelentett. Nyilvánvaló azonban az is, hogy ezen a területi egységen más népekkel, nemzetekkel, EU-tag és nem-EUtag államokkal osztozik a magyarság. Az egykori hatalmi térképződmény történeti ténye nem jelenti azt, hogy dominánsnak kell tekinteni a magyar kultúrát és másodrendủnek azokat a kultúrákat, amelyek a 20. században vezettek az új nemzetállamok kialakulásához. Az is igaz, hogy az etnikai térszerkezet változása, egy adott nemzet térvesztése az adott nemzethez tartozók számára érzelmileg, erkölcsileg nem elfogadható, és a nemzeti kisebbséghez tartozók asszimilációjának folyamata negatív érzéseket válthat ki a többséggel szemben.

${ }^{2}$ Szövegét 1921-ben írta Csanády György, zenéjét Mihalik Kálmán szerezte.
} 
${ }^{3}$ Voltak olyan időszakok is, amikor az osztrák katonai közigazgatás átmeneti változásokat hozott, mint az 1850-es években, azonban ezek emléke - a ,székiséggel” ellentétben - a mai köztudatban nem szerepel elevenen.

4 2009. március-április folyamán Hargita megyében 37 véleményformáló személyiséggel készítettünk részben strukturált interjúkat, azzal a céllal, hogy képet nyerjünk a turisztikai fogadókészség térségi elemeiről, az önkormányzati-közintézményi, vállalkozói és civil szféra döntéshozóinak a székelyföldi turizmusról alkotott felfogásáról, azzal szembeni attitüdjeiről. Az interjúk összegzéseit hat válaszcsoportba szerkesztettünk: 1) A turizmus jelentősége, pozitív és negatív hatások; 2) Turizmusfejlesztési feladatok: állam, önkormányzatok, vállalkozók, civilek; 3) Nemzeti/kisebbségi kultúra szerepe, a székelyföldi regionális identitás érvényesülése a turizmusban, térségmarketingben; 4) Jellegzetes turisztikai termékek, tevékenységek, helyszínek; 5) Jellegzetes turisták; 6) Szakoktatási intézmények, szakmák megítélése. E kutatási eredmények részletesebb közlése egy másik publikáció tárgyát fogja képezni.

\section{Irodalom}

Agg Z.-Nemes Nagy J. (2002) A politika térségi és helyi szintjei. - Bernek Á. (szerk.) A globális világ politikai földrajza. Nemzeti tankönyvkiadó, Budapest. 385-430. o.

A. Gergely A. (2005) Nemzeti vagy etnokulturális kisebbség? Megfontolások a kisebbségek kezelés- és megértésmódjához. - Kovács N.-Osvát A.-Szarka L. (szerk.) Etnikai identitás, politikai lojalitás. Nemzeti és állampolgári kötödések. Az MTA Etnikai-nemzeti Kisebbségkutató Intézetének Évkönyve 4. Budapest. 87-92. o.

Aubert A. (szerk.) (2007) A térségi turizmuskutatás és tervezés módszerei, eredményei. PTE TTK Földrajzi Intézet, Pécs.

Bakk M. (2004) Az autonómia-tervek két szakasza Erdélyben 1989 után. - Magyar Kisebbség. 1-2. 39-60. o.

Barth F. (1996) Régi és új problémák az etnicitás elemzésében. - Regio. 7. 1. 3-25. o.

Benedek J. (2000) A társadalom térbelisége és térszervezése. Risoprint Kiadó, Kolozsvár.

Benedek J. (2006) Területfejlesztés és regionális fejlödés. Presa Universitara Clujeana, Kolozsvár.

Bíró A.Z. (szerk.) (2007) Székelyföldi elitek jövooképe. Alutus Kiadó, Csíkszereda.

Bíró A.Z. (2008) Székelyföldi helyzetkép - önálló regionális fejlődés. - Térség. 1. 1. 7-26. o.

Church, A. (2004) Local and Regional Tourism Policy and Power. - Lew, A.A.-Hall, C.M.-Williams, A.M. (eds.): A Companion to Tourism. Blackwell Publishing, Malden-Oxford-Carlton. 555-568. o.

Cocean, P. (2002) Geografie regională. Evoluție, concepte, metodologie. Presa Universitară Clujeană, Cluj-Napoca.

Csutak I. (2007) Új? Régi? Jó? Új régiókat Romániának! Romániai Magyar Demokrata Szövetség, Marosvásárhely. (www.rmdsz.ro, letöltve 2009. nov. 17.)

Czene Zs. (2002) A kulturális örökség területfejlesztési megközelítése. - Tér és Társadalom. 4. 25-38. o.

Dower, M. (1999) Az örökség, mint erőforrás. A helyi fejlesztés egyik eszköze. - Falu 2. 77-85. o.

Egedy G. (2007) Gondolatok a nemzetröl. A politikai és kulturális megközelítés - Szarka L.-Vizi B Majtényi B.-Szarka L. (szerk.) Nemzetfogalmak és etnopolitikai modellek Kelet-Közép-Európában. MTA Etnikai-nemzeti Kisebbségkutató Intézet Évkönyve 6. Gondolat Kiadó, Budapest. 70-79. o.

Egyed Á. (2006) A székelyek rövid története a megtelepedéstöl 1918-ig. Pallas-Akadémia Könyvkiadó, Csíkszereda.

Elekes T. (2009) A székely székek térképe (az egykori Aranyosszék nélkül) Forrás: http://elekes.adatbank. transindex.ro/index.php (letöltve 2009. nov. 17.)

Faragó L. (2005) A jövöalkotás társadalomtechnikája. A közösségi tervezés elmélete. Dialóg Campus Kiadó, Budapest-Pécs.

Feischmidt M. (2005) A magyar nacionalizmus autenticitás-diskurzusainak szimbolikus térfoglalása Erdélyben. - Feischmidt M. (szerk.) Erdély-(de)konstrukciók. Tanulmányok. Néprajzi Múzeum-PTE Kommunikáció- és Médiatudományi Tanszék, Budapest - Pécs. 7-32. o.

Ferencz A. (2003) A kulturális örökség védelme, a kulturális ipar alapjai. - Horváth Gy. (szerk.) Székelyföld. A Kárpát-medence régiói 1. Dialóg Campus Kiadó, Budapest-Pécs. 326-352. o.

Glatz F. (szerk.) (1996) A magyarok krónikája. Officina Nova, Budapest.

Győri Szabó R. (2004) Kombinált autonómia és regionalizálás. Gondolatok az erdélyi autonómiatervezetek és vitaindító kapcsán. - Magyar Kisebbség. 1-2. 135-137. o. 
Győri Szabó R. (2006) Kisebbség, autonómia, regionalizmus. Osiris Kiadó, Budapest.

Hajdú Z. (2000) Erdély történetileg változó államföldrajzi problematikája: közigazgatási régió, részállam, önálló állam? - Boros L. (szerk.) Erdély természeti és társadalmi földrajza. A Nyírségi Földrajzi Napok elöadásai, 1999. okt. 20-22., Nyíregyháza. 323-337. o.

Hall, C.M. (1994) Tourism and Politics: Policy, Power and Place. John Wiley and Sons, ChichesterNew York-Brisbane-Toronto-Singapore.

Hall, C.M.-Jenkins, J. (2004) Tourism and Public Policy. - Lew, A.A.-Hall, C.M.- Williams, A.M. (eds.) A Companion to Tourism. Blackwell Publishing, Malden-Oxford-Carlton. 525-540. o.

Hardi T.-Hajdú Z.-Mezei I. (2009) Határok és városok a Kárpát-medencében. MTA RKK, Győr-Pécs.

Harron, S.-Weiler, B. (1992) Review. Ethnic Tourism. - Weiler, B.-Hall, C.M. (eds.) Special Interest Tourism. Belhaven Press, London. 83-94. o.

Hermann G.M. (2003) Náció és nemzet. Székely rendi nacionalizmus és magyar nemzettudat 1848-ig. Pro-Print Könyvkiadó, Csíkszereda.

Hermann G.M. (2007) Eltéritett múlt. Oklevél és krónikahamisitványok a székelyek történetében. ProPrint Könyvkiadó, Csíkszereda.

Horváth A. (2006) Délkelet-Erdély térségi turizmusfejlesztésének kihívásai. II. Országos Turisztikai Konferencia, Pécsi Tudományegyetem Természettudományi Kar, Turizmus Tanszék, Pécs. 2006. okt. 12-13. (CD-kiadvány) $11 \mathrm{o}$.

Horváth A. (2007) Székelyföld - a Kárpát-medence és Románia történeti-kulturális régiója. - Horváth R. (szerk.) A székelyföldi fejlesztés alapjai. RMDSZ Önkormányzati Főosztály, Helyi Önkormányzati Kutatócsoport Egyesület, Kolozsvár. 9-35. o.

Horváth A. (2009) Turizmus Hargita megyében: a térségfejlesztés eszköze? - Évkönyv. (Fiatal Regionalisták VI. Országos Konferenciájának előadásai, 2009. június 4-5.) Széchenyi István Egyetem Regionális- és Gazdaságtudományi Doktori Iskola, Győr. 175-185. o.

Horváth, A.-Peteley, A. (2008) Adapting the TDM-Model in the Development of Tourism in Harghita County. - Journal of Tourism Challenges and Trends. Ed. Universitară, Bucureşti. 45-60. o.

Horváth Gy. (szerk.) (2003) Székelyföld. A Kárpát-medence régiói 1. MTA Regionális Kutatások Központja-Dialóg Campus Kiadó, Budapest-Pécs.

Husz M. (2007) Hét fejezet a kulturális örökségturizmusról. PTE Felnőttképzési és Emberi Erőforrásfejlesztési Kar, Pécs.

Ilyés Z. (2003) Az emlékezés és az újratanulás terei - a ,honvágyturizmus”, mint tér- és identitásszervezés. - Fejös Z.-Szijártó Zs. (szerk.) Helye(in)k, tárgya(in)k, képe(in)k. A turizmus társadalomtudományos magyarázata. Tanulmányok. Néprajzi Múzeum, Budapest. 51-58. o.

Ilyés Z. (2005) A gyimesi „,ezeréves határ” olvasatai. - Feischmidt M. (szerk.) Erdély- (de)konstrukciók. Tanulmányok. Néprajzi Múzeum - PTE Kommunikáció- és Médiatudományi Tanszék, BudapestPécs. 35-49. o.

Kántor Z. (2007) Egy hamis dichotómia: politikai/kulturális nemzet. - Szarka L.-Vizi B.-Majtényi B.Szarka L. (szerk.) Nemzetfogalmak és etnopolitikai modellek Kelet-Közép-Európában. MTA Etnikainemzeti Kisebbségkutató Intézet Évkönyve 6. Gondolat Kiadó, Budapest. 80-91. o.

Kántor Z.-Majtényi B. (2004) Autonómia-modellek Erdélyben. Jövőkép és stratégia. - Magyar Kisebbség. 1-2. 3-29. o.

Kánya J. (2003a) Történeti áttekintés. - Horváth Gy. (szerk.) Székelyföld. A Kárpát-medence régiói 1. MTA Regionális Kutatások Központja - Dialóg Campus Kiadó, Budapest-Pécs. 27-65. o.

Kánya J. (2003b) A székelyföldi kollektív és a „széki” identitás változása. - Horváth Gy. (szerk.) Székelyföld. A Kárpát-medence régiói 1. MTA Regionális Kutatások Központja-Dialóg Campus Kiadó, Budapest-Pécs. 352-355. o.

Keményfi R. (2002) Az „etnicitás” fogalma és helye az etnikai térszerkezeti kutatásokban. - Kisebbségkutatás. 2. 376-384. o.

Kiss T.-Csata I. (2006) Népesedési perspektívák Erdélyben. - Határon túli magyarság a 21. században: tények és perspektívák. Válogatás a Köztársasági Elnöki Hivatal által szervezett konferencia előadásaiból, 2006. május 4. - Pro Minoritate. Nyár-Ösz. 37-58. o.

Kocsis K. (2002a) A Kárpát-medencei magyar kisebbségek jelenlegi települési és társadalmi szerkezete. - Magyarország és a magyar kisebbségek. Magyarország az ezredfordulón. Stratégiai kutatások a Magyar Tudományos Akadémián. Magyar Tudományos Akadémia, Budapest. 31-46. o.

Kocsis K. (2002b) Etnikai földrajz. - Tóth J. (szerk.) Általános társadalomföldrajz. Dialóg Campus Kiadó, Budapest-Pécs. 313-335. o.

Kocsis K.-Bottlik Zs.-Tátrai P. (2006) Etnikai térfolyamatok a Kárpát-medence határainkon túli régióiban (1989-2002). Magyar Tudományos Akadémia Földrajztudományi Kutatóintézet, Budapest. 
Kolumbán G. (2001) Az értékelvű társadalomépítés regionalizációs hatásai. - Papp Kincses E. -Kassay J.Kánya J. (szerk.) A kulturális térségek szerepe a regionális fejlesztésben. Válogatás a 2000 . Április 13-15. Tusnádfürdői konferencián elhangzott előadásokból. Székelyföld 2000 Munkacsoport, Csíkszereda. 7-14. o.

Kolumbán G. (2003) A Székelyföld esélyei a román területfejlesztési politika keretei közt. - Magyar Kisebbség. 2-3. 5-35. o.

Kovács P. (2004) Turizmusmarketing elméletben és gyakorlatban. Kodolányi János Főiskola, Székesfehérvár.

Kozma G. (2003) Terület- és településmarketing. Geográfus és földrajz tanár szakos hallgatók számára. Kossuth Egyetemi Kiadó, Debrecen.

KPMG Tanácsadó Kft. (2006) România percepută de Ungaria, ca destinație turistică. Tendintele de călătorie ale turiştilor maghiari. Raport final, 31 martie. (Studiu realizat pentru Biroul de promovare a turismului românesc din Budapesta).

Legea 190/2009 pentru aprobarea Ordonantei de urgenta a Guvernului 142/2008 privind aprobarea Planului de amenajare a teritoriului national Sectiunea a VIII-a - Zone cu resurse turistice. Monitorul Oficial al României. Nr. 387/ 09.06.2009. [törvény az Országos Területrendezési Terv, a turisztikai erőforrásokkal rendelkező övezetekről szóló VIII. szekciója elfogadásáról]

Lengyel M. (2004) A turizmus általános elmélete. Heller Farkas Gazdasági és Turisztikai Szolgáltatások Főiskolája, Budapest.

Lengyel M. (szerk.) (2008) TDM Müködési kézikönyv. Heller Farkas Főiskola, Budapest.

Lengyel I.-Rechnitzer J. (2004) Regionális gazdaságtan. Dialóg Campus Kiadó, Budapest-Pécs.

Márton J. (2004) Székelyföld területi autonómiája - Koncepciók és esélyek. - Magyar Kisebbség. 1-2. 138-139. o.

Michalkó G. (2007) A turizmuselmélet alapjai. Kodolányi János Főiskola, Székesfehérvár.

Nagy B., coord. (2009) Strategia de dezvoltare a turismului din județul Harghita. Aquaprofit Consulting Srl. - Consiliul Judetean Harghita, Miercurea-Ciuc.

Piskóti I.-Dankó L.-Schupler H. (2002) Régió- és településmarketing. KJK-KERSZÖV Jogi és Üzleti Kiadó Kft., Budapest.

Puczkó L.-Rátz T. (2000) Az attrakciótól az élményig. A látogatómenedzsment módszerei. Geomédia Kiadói Rt., Budapest.

Puczkó L.-Rátz T. (2001) A turizmus hatásai. Aula Kiadó - Budapesti Közgazdaság-tudományi és Államigazgatási Egyetem, Budapest.

Ritchie, J.R.B.-Crouch, G.I. (2003) The Competitive Destination. A Sustainable Tourism Perspective. CABI Publishing, Oxon, UK - Cambridge, MA, USA.

Sebestyén A. (2005) „Erdélybe utazni más”. A magyar turisztikai irodalom Erdély-képe. - Feischmidt M. (szerk.) Erdély- (de)konstrukciók. Tanulmányok. Néprajzi Múzeum-PTE Kommunikáció- és Médiatudományi Tanszék, Budapest - Pécs. 51-67. o.

Sós J.-Farkas Z. (2002) Erdély. Útikönyv. Jel-Kép Bt., Budapest.

Szarka L. (1999) A közép-európai kisebbségek tipológiai besorolhatósága. - Kisebbségkutatás. 2. 168-175. o.

Szarka L. (2005a) Identitás és lojalitás nemzetállami konfliktushelyzetei. - Kovács N.-Osváth A.Szarka L. (szerk.) Etnikai identitás, politikai lojalitás. Nemzeti és állampolgári kötődések. Az MTA Etnikai-nemzeti Kisebbségkutató Intézet Évkönyve 4., Budapest. 93-119. o.

Szarka L. (2005b) Alternatívák és irányzatok a magyar kisebbségpolitikában; Közösségépítés, konszociáció, nemzeti integráció. - Magyar Tudomány. 2. 188-199. o.

Szarka L. (2007) A kisebbségek helye a magyar nemzetfogalomban a 21. század elején. - Szarka L.Vizi B.-Majtényi B.-Kántor Z. (szerk.) Nemzetfogalmak és etnopolitikai modellek Kelet-KözépEurópában. Gondolat Kiadó, Budapest. 130-152. o.

Varga A. (2004) Autonómia - mint politikai beszédtéma, mint társadalmi igény, mint közjogi állapot. Magyar Kisebbség. 1-2. 211-225. o.

Veres V. (2005) Nemzeti identitás Erdélyben - szociológiai olvasatban. Az erdélyi magyarok és románok nemzeti identitásának sajátosságai, társadalmi rétegződési perspektívában. Akadémiai Kiadó, Budapest.

Vincze M. (2000) Régió- és vidékfejlesztés. Elmélet és gyakorlat. Presa Universitară Clujeană, Kolozsvár.

Vofkori L. (1998) Székelyföld útikönyve I-II. Cartographia Kft., Budapest.

Vörös G. (2005) A szakrális, a nemzeti közösség és az egzotikum élménye. A magyarországiak részvételének motivációiról a csíksomlyói pünkösdi búcsúban. - Feischmidt M (szerk.) Erdély (de)konstrukciók. Tanulmányok. Néprajzi Múzeum-PTE Kommunikáció- és Médiatudományi Tanszék, Budapest - Pécs. 69-84. o. 